I should also like to convey my thanks to Dr med. Helene Sonnemann of the Kinderhospital, Celle, who was instrumental in taking all the bloods for us, and to the members of the German staff in the laboratory at Celle, particularly Margret Fredenhagen, for carrying out the analyses, often in duplicate or triplicate.

\title{
REFERENCES
}

Barnes, D. J. \& Munk, B. (1940). Proc. Soc. exp. Biol., N.Y., 44, 327.

King, E. J. (1946). Micro-Analysis in Medical Biochemistry. London: Churchill.

Klasmer, R. (1944). Amer. F. Dis. Child. 67, 348.

Stearns, G. \& Warweg, E. (1933). F. biol. Chem. 102, 749.

\section{The Estimation of the Metabolic Rate in the Starvation State}

\author{
By J. BEATTIE and PHILIPPA H. HERBERT (Leverhulme Scholar) \\ Bernhard Baron Research Laboratories, Royal College of Surgeons of \\ England, Lincoln's Inn Fields, London, W.C: 2
}

(Received 3I Fuly I947)

In the classical studies of undernutrition in man, reviewed by Lusk (I92I), the basal metabolism was found to be reduced whether it was expressed in terms of heat production $/$ sq.m. of body surface or of heat production $/ \mathrm{kg}$. body-weight. The percentage fall in basal metabolism was, however, greater when it was calculated with reference to the surface area than when calculated in terms of heat production $/ \mathrm{kg}$. body-weight. This discrepancy was not discussed by Lusk who was concerned mainly with drawing attention to the fact that energy production in the starvation state is reduced below normal.

\section{EXPERIMENTAL}

\section{Selection of subjects}

Studies of energy metabolism in severely undernourished persons in Holland in 1945 and in Germany in 1946 revealed great discrepancies between the levels of basal metabolism when these were expressed in terms of heat production/sq.m. of body surface and of heat production $/ \mathrm{kg}$. body-weight. It appeared that the discrepancies increased with increased weight loss. We were unable at the end of our first study in I945 to decide which method of expressing the basal metabolism was the better index of the rate of tissue oxidation. In Germany we were able to study a group of young adults who, with one exception, were between the ages of $2 \mathrm{I}$ and $3 \mathrm{I}$ years. During a preliminary period of observation lasting 4 weeks, forty men between 20 and 40 years of age were studied while living on a diet containing not more than $175^{\circ} \mathrm{Cal}$./day and identical with that consumed during the preceding 3 months. By gradual elimination of subjects who had some clinical evidence of organic disease or a recent history of tuberculosis, 
a group of men was selected for metabolic studies. Those who gave, over the last 2 weeks of the preliminary period, basal oxygen consumptions which did not vary by more than $5 \%$ from day to day, formed the experimental group of eleven individuals. All these men had served in one or other branch of the German armed forces and consequently their normal body-weights were adequately documented. They had all been detained in a civil prison since July 1945 and the fall in body-weight during the period July I 945 -July 1946 could be followed as monthly weighings were carried out on all inmates.

\section{Methods}

It was assumed that, in their normal state, the heat production/sq.m. of body surface was that appropriate to their age as expressed in the standard tables of Boothby $\&$ Sandiford (1929). As these men had been trained during the preliminary period in the use of the spirometer it was necessary to make a deduction of $5 \%$ from the Boothby \& Sandiford standards to make a fair comparison between the calculated normal and the observed values. The surface areas of the body were calculated from the Du Bois \& Du Bois (I916) formula using the recorded normal body-weights and heights for the normal state and the observed weights and heights, at the end of the preliminary period of observation, as those for the starvation state. These data are contained in Table I. The 'normal' body-weight was the mean of all recorded weights during the period January-June I 945 where known, or, alternatively, the recorded body-weight when admitted to the penal institution (June or July 1945). The weight for the starvation state was that recorded on the morning of the first oxygen-consumption test day after the end of the preliminary period.

Table I. Changes in height, weight and surface area of eleven subjects

\begin{tabular}{|c|c|c|c|c|c|c|}
\hline \multirow[b]{2}{*}{ Subject } & \multicolumn{3}{|c|}{ Normal state } & \multicolumn{3}{|c|}{ Starvation state } \\
\hline & $\begin{array}{l}\text { Height } \\
\text { (cm.) }\end{array}$ & $\begin{array}{l}\text { Weight } \\
\text { (kg.) }\end{array}$ & $\begin{array}{l}\text { Surface area } \\
\text { (sq.m.) }\end{array}$ & $\begin{array}{l}\text { Height } \\
\text { (cm.) }\end{array}$ & $\begin{array}{l}\text { Weight } \\
\text { (kg.) }\end{array}$ & $\begin{array}{l}\text { Surface area } \\
\text { (sq.m.) }\end{array}$ \\
\hline Ks. & 182 & 71 & I'90 & $I 8 I \cdot 5$ & $55 \cdot 5$ & $I \cdot 71$ \\
\hline Lv. & 184 & 73 & $I \cdot 94$ & 184 & $55 \cdot 7$ & $x \cdot 72$ \\
\hline $\mathrm{Kl}$. & I 68 & 65 & $1 \cdot 73$ & 168 & $53 \cdot 2$ & $I \cdot 59$ \\
\hline Wz. & 169 & $71 \cdot 5$ & $I \cdot 84$ & 169 & $53 \cdot 8$ & $I \cdot 60$ \\
\hline Sc. & 166 & 69 & $x \cdot 92$ & 166 & $55 \cdot 7$ & $1 \cdot 60$ \\
\hline Gm. & I65 & 70.5 & $x \cdot 77$ & 165 & $50 \cdot 1$ & $I \cdot 53$ \\
\hline Gt. & 170 & 69 & $x \cdot 83$ & 170 & $48 \cdot 8$ & I.55 \\
\hline Rs. & 171 & 67 & $\mathrm{I} \cdot 78$ & 171 & $55 \cdot 3$ & $I \cdot 64$ \\
\hline Gd. & 170 & 69 & $x \cdot 79$ & 170 & $45 \cdot 5$ & $I \cdot 5 \mathrm{I}$ \\
\hline $\mathrm{Bm}$. & I 67 & 65 & $1 \cdot 72$ & 167 & $47 \cdot 9$ & $I \cdot 52$ \\
\hline Ru. & 170 & 70 & $I \cdot 80$ & I 70 & $53 \cdot 6$ & $I \cdot 6 I$ \\
\hline
\end{tabular}

Heat production was calculated from the oxygen consumption by assuming an R.Q. of 0.82 giving a calorific value for oxygen of $4.825 \mathrm{Cal} . / 1$. Details of the method used to find basal oxygen consumption have been described in another paper (Beattie \& Herbert, 1947). The heat production/sq.m. of body surface/hr. has been compared in Table 2 with the corrected standard value. The body-weight/sq.m. of surface has been calculated for both normal and starvation states. 
Table 2. Changes in basal heat production/sq.m./hr. and in body-zveight/sq.m. of eleven subjects

\begin{tabular}{|c|c|c|c|c|c|c|}
\hline \multirow[b]{2}{*}{ Subject } & \multicolumn{3}{|c|}{ Heat production (Cal./sq.m./hr.) } & \multicolumn{3}{|c|}{ Body-weight (kg./sq.m.) } \\
\hline & $\begin{array}{c}\text { Normal } \\
\text { (corrected), } \\
\text { calculated }\end{array}$ & $\begin{array}{c}\text { Starvation } \\
\text { state, } \\
\text { observed }\end{array}$ & $\begin{array}{l}\text { Change from } \\
\text { normal } \\
(\%)\end{array}$ & $\begin{array}{l}\text { Normal, } \\
\text { calculated }\end{array}$ & $\begin{array}{c}\text { Starvation } \\
\text { state, } \\
\text { observed }\end{array}$ & $\begin{array}{c}\text { Change from } \\
\text { normal } \\
(\%)\end{array}$ \\
\hline Ks. & $38 \cdot 9$ & 35.5 & -9 & $37 \cdot 3$ & $32 \cdot 4$ & $-I_{3}$ \\
\hline Lv. & $38 \cdot 3$ & $34 \cdot 2$ & $-\mathbf{I} \mathbf{I}$ & $37 \cdot 6$ & $32 \cdot 4$ & -14 \\
\hline K1. & $38 \cdot 9$ & $28 \cdot 3$ & -27 & $37 \cdot 6$ & $33 \cdot 4$ & $-I I$ \\
\hline Wz. & $38 \cdot 3$ & $35 \cdot 8$ & -6 & $38 \cdot 9$ & $33 \cdot 8$ & -13 \\
\hline Sc. & $38 \cdot 3$ & $32 \cdot 2$ & -16 & $35 \cdot 9$ & $34 \cdot 8$ & -3 \\
\hline Gm. & $38 \cdot 9$ & $30 \cdot 6$ & $-2 \mathbf{I}$ & $39 \cdot 8$ & $32 \cdot 8$ & -18 \\
\hline Gt. & $38 \cdot 9$ & $27 \cdot 5$ & -29 & $39^{\circ} 9$ & $3 I \cdot 5$ & $-2 I$ \\
\hline Rs. & $38 \cdot 9$ & $36 \cdot 4$ & -6 & $37 \cdot 6$ & $33 \cdot 7$ & -10 \\
\hline Gd. & $37 \cdot 8$ & $28 \cdot I$ & -26 & $38 \cdot 5$ & 30.1 & -22 \\
\hline $\mathrm{Bm}$. & $38 \cdot 3$ & 30.8 & -20 & $37 \cdot 8$ & $31 \cdot 5$ & -17 \\
\hline Ru. & $35 \cdot 3$ & 33.5 & -5 & $3^{8} \cdot 9$ & $33 \cdot 3$ & -14 \\
\hline & & Average & -16 & & & $-14 \cdot 2$ \\
\hline
\end{tabular}

Table 3 contains a comparison of heat production $/ \mathrm{kg}$. body-weight in the two states.

Table 3. Changes in basal heat production and in basal heat production $/ \mathrm{kg}$. body-weight/day of eleven subjects

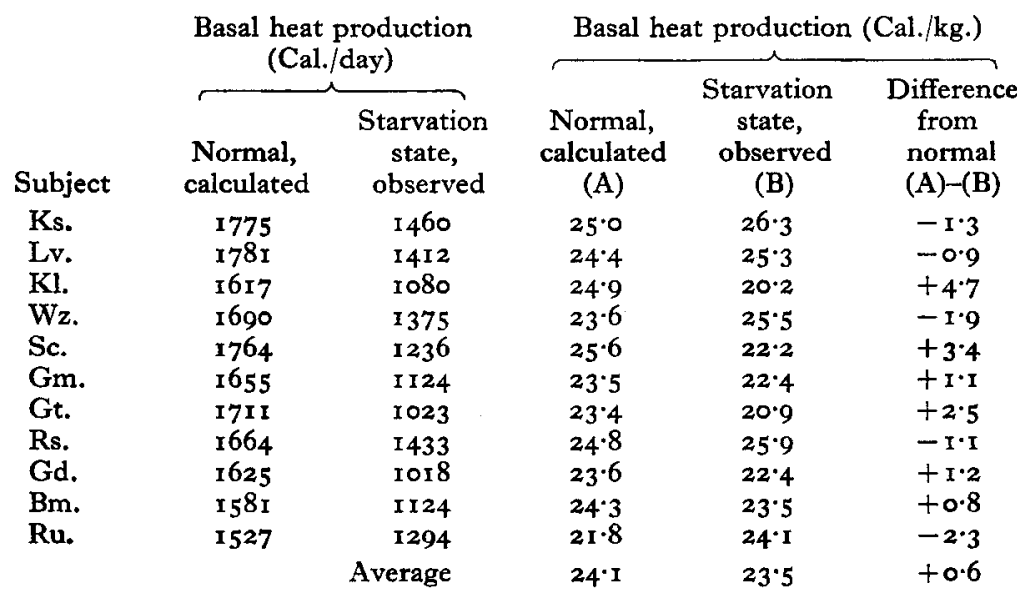

\section{RESULTS}

Heat production/sq.m.

The Rubner (1883, 1894) concept that in animals, including man, there is a relative constancy in heat production/unit surface area implies that, as the surface area/unit body-weight increases, the heat production/unit body-weight must increase proportionately. Thus, when an individual declines in weight, his surface area/unit bodyweight increases (Table 2), and, consequently, if heat production/unit surface is to remain constant, the heat production/unit body-weight must increase. For example, subject $\mathrm{Gd}$. had a calculated normal surface area of $\mathrm{r} \cdot 79$ sq.m. with a normal bodyweight of $69 \mathrm{~kg}$. The body-weight/sq.m. was, therefore, $38.5 \mathrm{~kg}$. In the starvation state his weight had declined to $45.5 \mathrm{~kg}$. and his surface area to $1 \cdot 5$ sq.m. Body- 
weight/sq.m. was thus $30 . \mathrm{I} \mathrm{kg}$. If heat production/sq.m. was to remain constant, then $3^{\circ} \cdot \mathrm{I} \mathrm{kg}$. would have to produce the same amount of heat/unit time in the starvation state as $38.5 \mathrm{~kg}$. produce under normal conditions. Heat production $/ \mathrm{kg}$. would thus have to rise to $(38 \cdot 5 / 30 \cdot \mathrm{I}) \times 100=\mathrm{I} 28 \%$ of the normal value. If, however, heat production $/ \mathrm{kg}$. body-weight remained unchanged, the heat production/sq.m. would fall to $(30 \cdot 1 / 38 \cdot 5) \times 100=79 \%$ of the normal level, i.e. a fall of $21 \%$. The observed fall in heat production/sq.m. in this individual was $26 \%$.

It is thus possible that the change in the ratio of body-weight to unit surface might be responsible for the change in the rate of heat production/sq.m. of surface. The average fall in heat production/sq.m. in Table 2 is $16.0 \%$. The average fall in bodyweight $/$ sq.m. is $14.2 \%$. If it were true that the fall in heat production/sq.m. is due to the fall in body-weight/sq.m. then the average percentage falls should be identical apart from error variation. There is, however, a difference of $1.8 \%(16 \cdot 0-14 \cdot 2)$ which may or may not be significant. The eleven values may be subjected to an analysis of variance which will contain two items, the first representing the departure of this mean difference from zero and the second representing the variation of the eleven values around the mean. By the customary methods this analysis appears as follows:

\begin{tabular}{lccc} 
& \multicolumn{3}{c}{$\begin{array}{c}\text { Degrees of } \\
\text { freedom }\end{array}$} \\
Item & Sum of squares & $(n)$ & Mean square \\
(1) Difference & $36 \cdot 36$ & I & $36 \cdot 36$ \\
(2) Error & $657 \cdot 63$ & IO & $65 \cdot 76$ \\
Total & 693.99 & I I & -
\end{tabular}

Further testing is unnecessary as it is obvious from inspection that the departure of the mean difference from zero is insignificant. So far as this test goes the fall in heat production/sq.m. would appear to be a mere reflexion of the fall in body-weight/sq.m.

\section{Heat production/kg. body-weight}

Benedict ( $193^{8}$ ) has advocated this method of expressing basal metabolism as the simplest, even if not necessarily the most accurate. We calculated the normal rate and the rate in the starvation state and have expressed the differences as percentages of the normal rates (Table 3 ). The average heat production $/ \mathrm{kg}$. body-weight in the normal state was $24 \cdot \mathrm{I}$ Cal., and in the starvation state $23.5 \mathrm{Cal}$.- a difference of $0.6 \mathrm{Cal}$. If heat production $/ \mathrm{kg}$. remained unchanged in the starvation state from that in the normal state, a zero difference might be expected. Testing the significance of this observed departure from an expected zero difference by an analysis of the variance of the eleven individual differences, we found:

$\begin{array}{llcc}\text { Item } & \text { Sum of squares } & \begin{array}{c}\text { Degrees of } \\ \text { freedom }\end{array} \\ \text { (I) Difference } & 3.49 & \text { I } & \text { Mean square } \\ \text { (2) Error } & 52.31 & \text { IO } & 3.49 \\ \text { Total } & 55.80 & \text { II } & 5.23\end{array}$

It is obvious that the departure of the mean difference from zero is not significant. $\mathrm{We}$ are thus justified in concluding that in the starvation state the heat production $/ \mathrm{kg}$. body-weight is not significantly different from that in the normal state. 


\section{Heat production/kg. active material}

When body-weight declines owing to inadequate food intake the active material in the body may not diminish proportionately. In another paper (Beattie, Bell \& Herbert, unpublished) we show that the total volume of the extra-cellular fluid (thiocyanatespace volume) in the body shows no significant change in absolute amount from that calculated for the normal body-weight. All the subjects in the present study had such 'normal' thiocyanate-space volumes. On the other hand, their body fat, which can be regarded as inert matter during the period of the oxygen-consumption test, was markedly diminished. It is conceivable, therefore, that, as body-weight falls, the absolute loss of body fat may be compensated for by the constancy of the extracellular fluid and hence, for a time at least, the ratio of active to inert material in the body may show no significant change.

Henschell, Mickelsen, Taylor \& Keys (1947), as the result of a study of normal adult males subjected to severe food deprivation, came to the conclusion that the thiocyanatespace fluid formed on the average $23.5 \%$ of the normal body-weight and that this fluid volume remained constant after 24 weeks of semi-starvation. Keys (r947) also showed by-specific gravity measurements that the body fat fell from $10 \%$ of the normal bodyweight to $3 \%$ of the observed body-weight at the end of the period of semi-starvation. He was unable to demonstrate any loss in bone density (observed radiographically) after semi-starvation. Using these data for these three inert constituents of the bodyweight, and assuming that the other inert materials in the body either form an insignificant part of the body-weight or decline in weight proportionately with the fall in the body-weight, we calculated that $62.5 \%$ of the body-weight is metabolically active. The active material in the body-weight in the starvation state was calculated by assuming that the extra-vascular-fluid weight remained constant at the normal value, that the body fat formed $3 \%$ of the observed body-weight and that the bone salts formed $4 \%$ of the normal body-weight.

We calculated heat production $/ \mathrm{kg}$. active material for the normal and starvation states (Table 4) and expressed the differences between the normal and starvation values as percentages of the normal. As we have pointed out already that heat production in the starvation state, expressed $/ \mathrm{kg}$. body-weight, did not differ significantly from that in the normal state, it was to be expected that no significant difference would be found between heat productions $/ \mathrm{kg}$. active material in the two states. The average heat production $/ \mathrm{kg}$. active material was $38.5 \mathrm{Cal}$. in the normal state and 38.6 in the starvation state. This difference is obviously not significant but for the sake of completeness we have analysed the variance of the eleven individual differences by the method employed above:

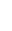

\section{Item}

(I) Difference

(2) Error

Total
Sum of squares 0.06 I 5 I.04 I 5 I. IO

$\begin{array}{cc}\begin{array}{c}\text { Degrees of } \\ \text { freedom } \\ (n)\end{array} & \text { Mean square } \\ \text { I } & 0.06 \\ \text { IO } & \text { r. } 50 \\ \text { I I } & -\end{array}$


Table 4. Changes in estimated active material content and in heat production $/ \mathrm{kg}$. active material of eleven subjects

Active material content as percentage

of body-weight

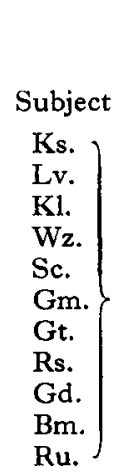

Heat production Cal. $/ \mathrm{kg}$. active material

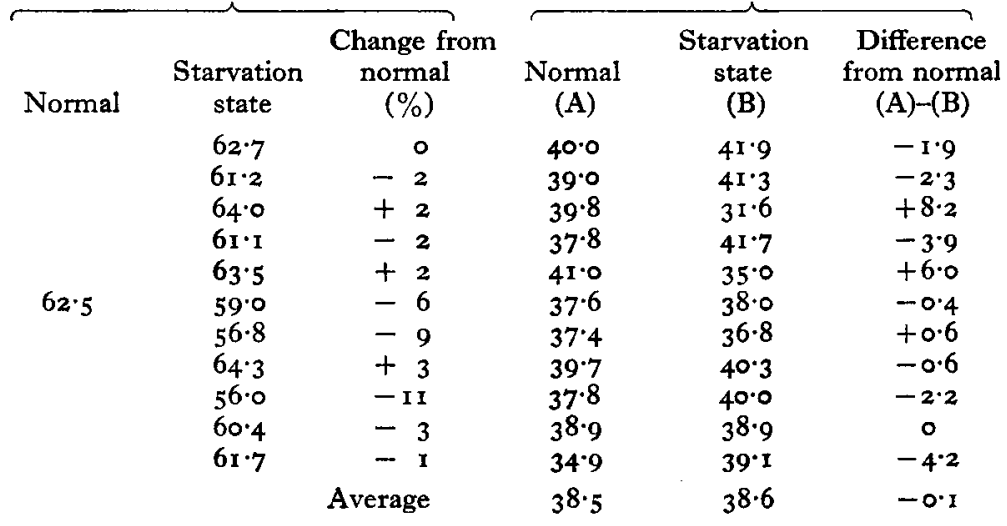

\section{DISCUSSION}

It would be tempting to conclude that heat production $/ \mathrm{kg}$. active material is an even better index of the metabolic level than heat production $/ \mathrm{kg}$. body-weight. The results would agree with such a conclusion but they do not demonstrate its validity unambiguously, for we have pointed out above that on the basis of heat production $/ \mathrm{kg}$. bodyweight there is no significant difference between the basal metabolism of the two states.

Table 5. Comparison of percentage change in body-weight and percentage change in active material/kg. body-weight of eleven subjects

$\begin{array}{ccc}\text { Subject } & \begin{array}{c}\text { Percentage change in } \\ \text { body-weight } \\ \text { (starvation state) }\end{array} & \begin{array}{c}\text { Percentage change in } \\ \text { active material } \\ \text { (starvation state) }\end{array} \\ \text { Rs. } & -17 & +3 \\ \text { Kl. } & -18 & +2 \\ \text { Sc. } & -19 & +2 \\ \text { Ks. } & -22 & -1 \\ \text { Ru. } & -23 & -1 \\ \text { Lv. } & -25 & -2 \\ \text { Wz. } & -25 & -2 \\ \text { Bm. } & -26 & -6 \\ \text { Gm. } & -29 & -9 \\ \text { Gt. } & -33 & -11 \\ \text { Gd. } & -34 & \end{array}$

The probable reason for our inability to select heat production $/ \mathrm{kg}$. active material as a better index of basal metabolism than heat production $/ \mathrm{kg}$. body-weight lies in the fact that the percentage of active material in the body shows little change until the weight loss exceeds $26 \%$ (Table 5). Only three subjects out of eleven showed weight losses exceeding $26 \%$ and these had changes in the active material percentage of -6 , -9 and $-\mathrm{rr} \%$. We have pointed out above how the loss of body fat is compensated for by the constancy of the extra-cellular-fluid volume. Apparently this compensation 
ceases to be effective in maintaining an almost constant ratio of active to inactive material in the body-weight under starvation conditions only when the loss in bodyweight exceeds about $26 \%$ of the normal body-weight.

\section{SUMMARY}

I. The heat production/sq.m. of body surface/kg. body-weight and the heat production $/ \mathrm{kg}$. active tissue have been calculated for a series of eleven individuals who had suffered considerable weight loss as the result of long-continued undernourishment.

2. The normal heat production of these individuals was calculated from normal standards with a deduction of $5 \%$ for the effect of training in the use of the spirometer.

3. The fall in heat production/sq.m. body surface in the starvation state proved to be related to a fall in the ratio of body-weight to body surface. For this reason this method of expressing basal metabolic rate gives no index of the rate of heat production (oxygen utilization) in the tissues.

4. The rate of heat production $/ \mathrm{kg}$. body-weight was not significantly different in the starvation state from the calculated normal rate so expressed.

5. An attempt was made to compare heat production $/ \mathrm{kg}$. active tissue in the two states. There was a suggestion that this method of expressing metabolic rate may be better than that based on gross body-weight but the data do not demonstrate unambiguously the validity of such a suggestion.

6. The change in the ratio of active material to the body-weight was greater than $5 \%$ only when the loss of body-weight exceeded $26 \%$ of normal weight.

7. The data obtained from the eleven subjects indicate that, under the observed conditions, the metabolic activity in the tissues did not deviate significantly from the normal.

We wish to thank Dr K. Mather for advising on the statistical analysis of our data. We are grateful to Dr Ancel Keys for permitting us to compare our data on thiocyanate volumes with those of his group prior to publication of his material, and for allowing us to make use of the unpublished work of his group of workers in our calculations of active material in the body-weight.

\section{REFERENCES}

Beattie, J. \& Herbert, P. H. (1947). Brit. F. Nutrit. I, 192.

Benedict, F. G. (1938). Publ. Carneg. Instn, no. 503.

Boothby, W. M. \& Sandiford, I. (1929). Amer. F. Physiol. 8o, 290.

Du Bois, D. \& Du Bois, E. F. (I916). Arch. intern. Med. 17, $86_{3}$.

Henschell, A., Mickelsen, O., Taylor, H. L. \& Keys, A. (1947). Amer. F. Physiol. r5o, I7o.

Keys, A. (1947). Personal communication.

Lusk, G. (1921). Physiol. Rev. x, 523.

Rubner, M. (1883). Z. Biol. 19, 535.

Rubner, M. (1894). Z. Biol. 30, 73. 